\title{
Prognostic Factors in Seminomas with Special Respect to HCG: Results of a Prospective Multicenter Study
}

\author{
L. Weissbach $^{a} \quad$ R. Bussar-Maatz ${ }^{a} \quad$ U. Löhrs ${ }^{b} \quad$ G.E. Schubert ${ }^{c} \quad$ K. Mann ${ }^{d}$ \\ M. Hartmann e K.P. Dieckmann ${ }^{f}$ J. Fassbinderg \\ for the Seminoma Study Group ${ }^{1}$
}

\begin{abstract}
${ }^{a}$ Abteilung für Urologie, Krankenhaus Am Urban, Berlin; b Institut für Pathologie, Universität München; cInstitut für Pathologie, Klinikum Barmen, Wuppertal; 'dStudienlaboratorium, Abteilung für Endokrinologie, Medizinische Klinik, Universität München; 'Abteilung für Urologie, Bundeswehrkrankenhaus Hamburg; ${ }_{f}^{f}$ Abteilung für Urologie, Albertinen-Krankenhaus, Hamburg, 9 Institut für medizinische Informatik, Biometrie und Epidemiologie, Universität Essen, Deutschland
\end{abstract}

\section{Key Words}

Seminoma, prognostic factors $\cdot$ Human chorionic gonadotropin - Multicenter study, seminoma • Radiotherapy

\begin{abstract}
Objective: In a prospective multicenter trial, it was our intention to elucidate clinical prognostic factors of seminomas with special reference to the importance of human chorionic gonadotropin (HCG) elevations in histo-
\end{abstract}

Participating hospitals with $\geq 5$ evaluable cases: Kantonspital, Basel; Krankenhaus Moabit, Berlin; Klinikum Benjamin Franklin, Berlin; Krankenhaus Am Urban, Berlin; Urologische Universitätsklinik, Bonn; Krankenanstalten, Düren; Klinik Golzheim, Düsseldorf; Bundeswehrkrankenhaus, Hamburg; Urologische Universitätsklinik, Hannover; Allgemeines Öffentliches Krankenhaus, Klagenfurt; Krankenhaus Holweide, Köln; Urologische Universitätsklinik, Lübeck; Marienhospital, Marl; Elisabeth-Krankenhaus, Mönchengladbach-Rheydt; Klinikum Grosshadern, München; Landeskrankenanstalten, Salzburg; Städtisches Krankenhaus, Salzgitter-Bad; Evangelisches Jung-Stilling-Krankenhaus, Siegen; Katharinenhospital, Stuttgart; Krankenhaus der Barmherzigen Brüder, Trier; Krankenhaus der Barmherzigen Brüder, Wien; Krankenhaus Rudolfstiftung, Wien; Universitätsklinik, Wien; Stadtkrankenhaus, Worms; Klinikum Barmen, Wuppertal.

\begin{tabular}{ll}
\hline KARGER & ( ) 1999 S. Karger AG, Basel \\
0302-2838/99/0366-0601\$17.50/0 \\
$\begin{array}{l}\text { Fax +4161306 12 34 } \\
\begin{array}{l}\text { E-Mail karger@karger.ch } \\
\text { www.karger.com }\end{array}\end{array}$ & $\begin{array}{l}\text { Accessible online at: } \\
\text { www.karger.com/journals/eur }\end{array}$
\end{tabular}

logically pure seminomas. Methods: Together with 96 participating urological departments in Germany, Austria, and Switzerland, we recruited 803 seminoma patients between 1986 and 1991. Out of 726 evaluable cases, 378 had elevated, while 348 had normal HCG values in the cubital vein. Histology was reviewed by two reference pathologists. HCG levels were determined in local laboratories and in a study laboratory. Standard therapy was defined as radiotherapy in stages I (30 Gy) and IIA/B (36 Gy) to the paraaortal and the ispilateral (stage I) and bilateral (stage IIA/B) iliac lymph nodes; higher stages received polychemotherapy and surgery in case of residual tumor masses. Statistics included chisquare tests, linear Cox regression, and log-rank test. Results: The HCG elevation is associated with a larger tumor mass (primary tumor and/or metastases). HCGpositive and HCG-negative seminomas had no different prognostic outcome after standard therapy. The overall relapse rate of $6 \%$ and the survival rate of $98 \%$ after 36 months (median) indicate an excellent prognosis. The calculation of the relative risk of developing a relapse discovered only stage of the disease and elevation of the lactate dehydrogenase concentration and its prolonged

Prof. Lothar Weissbach

Krankenhaus Am Urban, Dieffenbachstrasse 1

D-10967 Berlin (Germany)

Tel. +49 3069726300 , Fax +49 3069726306

E-Mail urourban@berlin.snafu.de 
marker decay as independent prognostic factors for seminomas. A more detailed analysis of the prognostic significance of the stage revealed that the high relapse rate in stage IIB seminomas after radiotherapy $(24 \%)$ is responsible for this result. Conclusions: We conclude that HCG-positive seminomas do not represent a special entity. Provided standard therapy is applied, HCG has no influence on the prognosis. Patients with stage IIB disease should be treated with chemotherapy because of the demonstrated higher relapse rate outside the retroperitoneum.

Copyright $\odot 1999$ S. Karger AG, Basel

\section{Introduction}

Elevations of human chorionic gonadotropin (HCG) levels in histologically pure seminomas lead to conjectures about the histological origin, the prognosis, and the adequate therapy of these tumors.

While elevated $\alpha$-fetoprotein (AFP) levels are inconsistent with the diagnosis of a pure seminoma [1], immunohistochemistry was able to demonstrate syncytiotrophoblastic giant cells and even mononuclear seminoma cells to be the origin of the HCG production [2,3]. Moreover, marker investigations of blood samples of the testicular vein demonstrated that nearly all seminomas are able to produce HCG [4]. Reviewing the published results of other investigators, we revealed an incidence of about $20 \%$ of the seminomas with elevated HCG serum titers in the cubital vein and that a positive immunohistological staining was successful in only $14 \%$ of the cases [5].

The supposed poor prognosis of HCG-positive seminomas was supported [6-9] or refuted [10-19] by reports on small series. It was discussed, whether it represented an intermediate form between seminomas and nonseminomas [20]. This disagreement contributed to the uncertain situation and resulted in various recommendations to treat HCG-positive seminomas. At the Consensus Conference in Hull [21] it was suggested to regard patients with $\mathrm{HCG}$ values $>200 \mathrm{U} / 1$ as having nonseminomas.

In 1986 we initiated a prospective multicenter trial to assess prognostic factors of seminomas with special regard to the influence of HCG. In this paper, we want to clarify the mystery surrounding HCG-positive seminomas: (1) Do HCG-positive and negative seminomas have different stage distributions? (2) Do they have a different prognostic outcome after standard therapy? (3) Are there any other prognostic factors than HCG elevations in seminomas?
Table 1. Distribution of HCG values in HCG-positive seminomas $(n=375)$

\begin{tabular}{crr}
\hline HCG, IU/1 & \multicolumn{1}{c}{$\mathrm{n}$} & $\%$ \\
\hline$<30$ & 182 & 49 \\
$20-50$ & 61 & 16 \\
$50-200$ & 68 & 18 \\
$200-1,000$ & 40 & 11 \\
$>1,000$ & 24 & 6 \\
\hline
\end{tabular}

\section{Patients and Methods}

All patients having seminomas with serologically positive HCG entered the study. AFP-positive tumors were excluded. Between January 1986 and December 1991, 803 patients from 96 urological departments were recruited, 515 of these prospectively.

77 patients had to be excluded (elevated AFP, nonseminomas, extragonadal tumors, missing data); in 8 patients the reference pathologist found nonseminomatous elements. 726 cases were evaluable. Out of them, 378 had elevated HCG levels in the cubital vein before $(n=375)$ or after $(n=3)$ orchiectomy (table 1). 348 patients had normal HCG values. Overall, marker determinations were performed in 726 patients for HCG and AFP, in 440 for lactate dehydrogenase (LDH) and in 174 for PIAP. The markers were determined in local laboratories by using different commercial assays. A second sample was sent to the study laboratory in Munich. The tumor markers were considered elevated, if the values exceeded the normal ranges. To determine a normal/prolonged marker decay, we used half-lives of $36 \mathrm{~h}$ for HCG and of $24 \mathrm{~h}$ for LDH and PIAP. However, we had to consider that the markers could be evaluated only according to the clinical stage.

For staging purposes we used the following classification: I - no metastases; IM - no visible metastases, but elevated tumor markers after orchiectomy: IIA - solitary lymph node metastasis $<2 \mathrm{~cm}$; IIB $_{1}$ - multiple lymph node metastases $<2 \mathrm{~cm}$; IIB 2 - lymph node metastases $2-5 \mathrm{~cm}$; IIC - lymph node metastases $>5 \mathrm{~cm}$, and III - lymph node metastases above the diaphragm and/or distant metastases.

We recommended a stage-dependent therapy: stage I - infradiaphragmatic radiation with $30 \mathrm{~Gy}$ (ipsilateral iliacal lymph nodes); stage IIA/B - infradiaphragmatic radiation with 36 Gy (with iliacal lymph nodes included), and stages IM, IIC, and III - primary chemotherapy and/or surgical resection of residuals. However, RPLND and adjuvant chemotherapy in stage IIA/B were allowed because of the uncertainty in that stage. $84 \%$ of the patients received standard therapy (radiotherapy in stage I-IIB and polychemotherapy and surgery in case of residual tumor masses in stage IIC-III). The median radiation dose was 30 (range 26-36) Gy in stage I and 36 (range 30-41) Gy in stage IIA/B.

\section{Statistics}

For a suggested association between two continuous variables, the linear correlation was used. Independent variables were tested by a chi-square (Pearson test with Yates' correction, and for special tests with low cell counts, Fisher's exact test was used. To illustrate differences in progression risk for stage and for HCG status, Kaplan-Meier 
curves are given. A multivariate analysis of prognostic variables seemed not to be appropriate because the numbers of relapses were too low ( $6 \%$ of the whole group). The Cox proportional hazards model was used in order to assess how a putative prognostic factor actually affects the risk of progression. As tumor stage is obviously a prognostic factor, the other variables were stratified according to the four levels 'stage I', 'stage IIA', 'stage IIB', and 'stage IIC/III'. The stratified relative risk estimates can be interpreted as the excess risk modification when the stage is already considered. Unstratified risk estimates are given for comparison. All relative risk estimates are calculated along with confidence intervals at the local 5\% level. Continuous variables have been polychotomized at clinically motivated points. Patient not receiving standard therapy have been excluded from this analysis. Patients who developed a secondary tumor or a contralateral testicular tumor were considered observed without progression up to that point and censored at that point.

\section{Results}

The stage distribution (for this analysis we used only those patients who were consecutively documented in 14 of the participating hospitals) showed significant differences for HCG-positive and HCG-negative seminomas. $72 \%$ of all patients had stage I disease. HCG-positive seminomas were more often associated with metastatic disease than HCG-negative cases (37 vs. $18 \%$, p < 0.0001 ), predominantly with larger retroperitoneal lymph node metastases.

8 of 515 prospectively enrolled patients had nonseminomatous elements when the histological slides were reviewed. Immunohistochemistry was positive in 59\% of the serologically HCG-positive seminomas.

$98 \%$ of the patients are alive after a median follow-up period of 36 months after standard therapy. 7 patients died of their disease, and 3 patients died of therapy-related complications (leukopenia after chemotherapy for multiple relapses, pulmonal embolism under chemotherapy for relapse after radiotherapy, and respiratory insufficiency after retroperitoneal lymph node dissection after chemotherapy). 3 patients died of other causes, and a further 2 of unknown reasons. 42 patients (6\%) developed a relapse, $22(3 \%)$ a contralateral testis tumor, and $9(1 \%)$ a secondary nontesticular carcinoma.

There were no differences in the relapse-free survival rates between HCG-positive and HCG-negative seminomas. Significant associations between relapse and $\mathrm{pI}$ category, LDH level elevation, and metastases could be established (table 2). The HCG level had no influence on the prognosis of the outcome: either a simple elevation or levels $>200 \mathrm{U} / 1$ or a prolonged marker decay. A multivariate analysis was not done because of the small number of relapses.
Table 2. Univariate analysis of parameters predictive for progressive disease 24 months after standard therapy

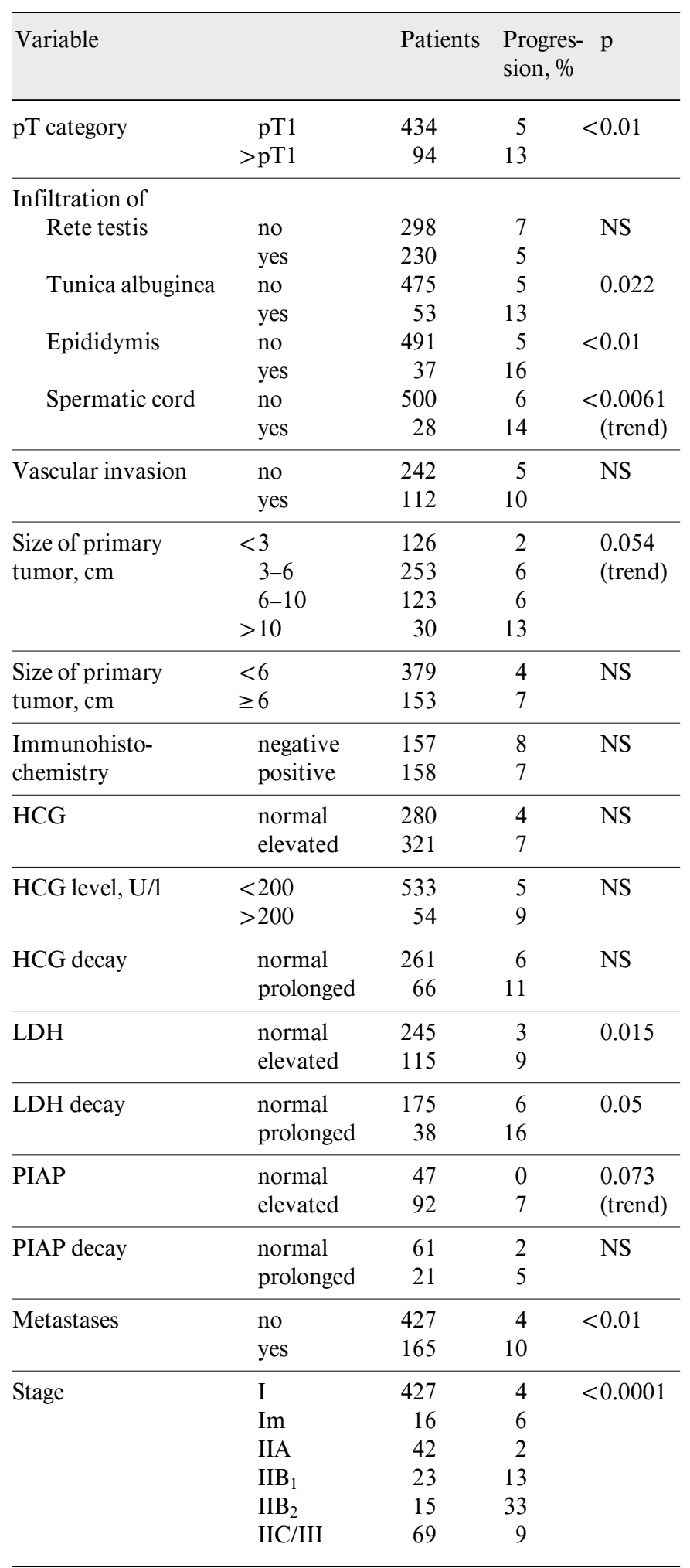

Eur Urol 1999;36:601-608 
Table 3. Relative risk rates for different levels of diagnostic measures, stratified according to tumor stage

\begin{tabular}{|c|c|c|c|c|c|c|c|c|}
\hline \multirow[t]{2}{*}{ Level } & \multirow{2}{*}{$\begin{array}{l}\text { Number } \\
\text { of } \\
\text { patients }\end{array}$} & \multirow{2}{*}{$\begin{array}{l}\text { Number of } \\
\text { patients with } \\
\text { progression }\end{array}$} & \multicolumn{3}{|c|}{$\begin{array}{l}\text { Nonstratified risk with } \\
95 \% \text { confidence interval }\end{array}$} & \multicolumn{3}{|c|}{$\begin{array}{l}\text { Stratified risk with } \\
95 \% \text { confidence interval }\end{array}$} \\
\hline & & & $\begin{array}{l}\text { lower } \\
\text { boundary }\end{array}$ & $\begin{array}{l}\text { relative } \\
\text { risk }\end{array}$ & $\begin{array}{l}\text { upper } \\
\text { boundary }\end{array}$ & $\begin{array}{l}\text { lower } \\
\text { boundary }\end{array}$ & $\begin{array}{l}\text { relative } \\
\text { risk }\end{array}$ & $\begin{array}{l}\text { upper } \\
\text { boundary }\end{array}$ \\
\hline Stage I & 454 & 18 & & & & & & \\
\hline Stage IIA & 44 & 1 & 0.1 & 0.6 & 4.2 & & & \\
\hline Stage IIB & 38 & 8 & 2.4 & 5.6 & 12.8 & & & \\
\hline Stage IIC/III & 69 & 7 & 1.2 & 2.8 & 6.7 & & & \\
\hline No metastases & 438 & 17 & & & & & & \\
\hline Metastases & 167 & 17 & 1.4 & 2.7 & 5.3 & & & \\
\hline Missing & 61 & 6 & & & & & & \\
\hline Tumor size $<3 \mathrm{~cm}$ & 128 & 2 & & & & & & \\
\hline Tumor size $3-6 \mathrm{~cm}$ & 262 & 15 & 0.6 & 1.4 & 3.3 & 0.6 & 1.4 & 3.3 \\
\hline Tumor size $6-10 \mathrm{~cm}$ & 124 & 7 & 0.5 & 1.4 & 3.8 & 0.4 & 1.1 & 3.1 \\
\hline Tumor size $>10 \mathrm{~cm}$ & 26 & 4 & 0.9 & 3.1 & 10.4 & 0.6 & 2.2 & 8.0 \\
\hline Missing & 65 & 1 & & & & & & \\
\hline $\mathrm{pT}_{1}$ & 444 & 21 & & & & & & \\
\hline $\mathrm{pT}_{2}$ & 68 & 8 & 1.3 & 3.0 & 6.7 & 1.0 & 2.2 & 5.1 \\
\hline $\mathrm{pT}_{3}$ & 28 & 4 & 1.3 & 3.8 & 10.9 & 0.9 & 2.6 & 8.0 \\
\hline Missing & 65 & 1 & & & & & & \\
\hline Infiltration of rete testis & 305 & 21 & 0.3 & 0.7 & 1.4 & 0.4 & 0.8 & 1.6 \\
\hline Missing & 65 & 1 & & & & & & \\
\hline Infiltration of tunica albuginea & 485 & 26 & 1.1 & 2.5 & 5.9 & 1.0 & 2.4 & 5.6 \\
\hline Missing & 65 & 1 & & & & & & \\
\hline Infiltration of epididymis & 503 & 27 & 1.5 & 3.7 & 8.9 & 0.8 & 2.0 & 5.2 \\
\hline Missing & 65 & 1 & & & & & & \\
\hline Infiltration of germinal cord & 512 & 29 & 1.0 & 2.8 & 8.1 & 0.7 & 2.0 & 6.0 \\
\hline Missing & 243 & 9 & & & & & & \\
\hline No vascular invasion & 247 & 14 & & & & & & \\
\hline Vascular invasion & 115 & 11 & 0.7 & 1.6 & 3.6 & 0.6 & 1.4 & 3.1 \\
\hline Missing & 61 & 6 & & & & & & \\
\hline Negative immunohistochemistry & 164 & 12 & & & & & & \\
\hline Positive immunohistochemistry & 158 & 13 & 0.5 & 1.2 & 2.6 & 0.5 & 1.2 & 2.6 \\
\hline HCG normal & 349 & 15 & & & & & & \\
\hline HCG elevated & 256 & 19 & 0.9 & 1.8 & 3.5 & 0.7 & 1.4 & 2.8 \\
\hline $\mathrm{HCG}<200 \mathrm{U} / 1$ & 550 & 58 & & & & & & \\
\hline $\mathrm{HCG}>200 \mathrm{U} / 1$ & 55 & 6 & 0.9 & 2.1 & 5.1 & 0.7 & 1.7 & 4.5 \\
\hline Missing & 270 & 11 & & & & & & \\
\hline HCG decay normal & 269 & 15 & & & & & & \\
\hline HCG decay prolonged & 66 & 8 & 0.9 & 2.2 & 5.2 & 0.6 & 1.7 & 4.7 \\
\hline Missing & 234 & 17 & & & & & & \\
\hline LDH normal & 269 & 15 & & & & & & \\
\hline LDH elevated & 117 & 10 & 1.2 & 3.2 & 8.4 & 1.1 & 3.1 & 8.8 \\
\hline Missing & 386 & 16 & & & & & & \\
\hline LDH decay normal & 182 & 11 & & & & & & \\
\hline LDH decay prolonged & 37 & 7 & 1.2 & 3.2 & 8.3 & 1.0 & 3.0 & 9.5 \\
\hline Missing & 464 & 27 & & & & & & \\
\hline PIAP normal & 47 & 0 & & & & & & \\
\hline PIAP elevated & 94 & 7 & - & - & - & - & - & - \\
\hline Missing & 520 & 32 & & & & & & \\
\hline PIAP decay normal & 65 & 1 & & & & & & \\
\hline PIAP decay prolonged & 20 & 1 & 0.2 & 3.3 & 52.8 & 0.4 & 6.2 & 98.9 \\
\hline
\end{tabular}


Fig. 1. Stage-related relapse-free survival of

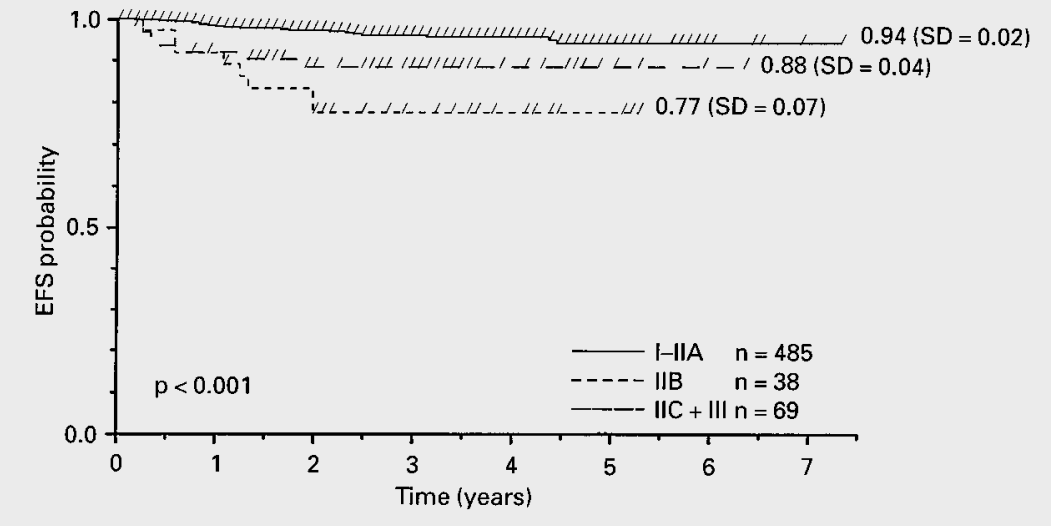
patients with seminomas after standard therapy. EFS = Event-free survival.

Instead of this, we calculated the relative risk of developping a relapse (table 3): stage IIB had the highest risk after radiotherapy. Moreover, an elevation of the LDH level and its prolonged marker decay seem to be independent predictive factors for a relapse because the relative risk does not change when we stratify for clinical stage.

The cumulative relapse-free 3-year survival rate in stage I was $94 \%$ for HCG-positive and $96 \%$ for HCG-negative seminomas. The results in stage IIA (one positive node $<2 \mathrm{~cm}$ ) were similar. Patients with stage IIB had a worse prognosis after radiotherapy, especially when the lymph nodes exceeded $2 \mathrm{~cm}$ (tables 2, 3). The relapse rate of irradiated stage IIB patients is even higher than that of patients with more advanced stages after chemotherapy. Comparison of the relapse rate of stage IIB patients revealed a significant difference from patients with lower stages and an obvious but not significant difference from patients with higher stages (fig. 1).

Details of the relapsing patients are summarized in table 4 . 6 or 7 patients out of 9 developed their relapse outside the retroperitoneum.

\section{Discussion}

The primary histological diagnostic error was very low, as only $1.5 \%$ of the patients had nonseminomatous elements in the histological material reviewed. In our series, the meticulous histological investigations resulted in a better correlation between the serologically measured HCG values and the immunohistochemical staining than described in the literature. $59 \%$ of the specimens stained positive, whereas the early publications reported on $14 \%$ HCG-positive stainings by immunohistochemistry [5]. During the course of the study, it was shown that about $80 \%$ of the patients with seminomas had elevated HCG values in the testicular vein, even when the samples from the cubital vein were negative $[4,22]$. Today, we have to assume that each seminoma is able to produce HCG. This assumption is supported by the fact that HCG could be stained in STGC or mononuclear seminomas despite negative serum values. Thus, we have to conclude that an HCG-positive seminoma is not a special entity.

We could demonstrate that pathological HCG levels are correlated with the total tumor burden, i.e., the size of the primary tumor as well as the stage of the disease [23]. Our data confirm the results of other authors who found higher stages in seminomas with HCG or LDH elevations $[1,24,25]$.

The prognosis of HCG-positive seminomas has been a subject of debate. Some investigators have observed the same good results as for HCG-negative seminomas [10, $14,16,18,19,26-28]$, while others stated a poorer outcome $[6,7,17,29-32]$. Nearly all reports were based on small, retrospectively documented series. Only the retrospective analysis of Mirimanoff et al. [25] attained 132 HCG-positive cases from ten centers in Switzerland. Schwartz et al. [33] reported on 191 stage I seminomas that could be completely reviewed, retrospectively. $13 \%$ of them had preoperatively elevated serum levels of HCG. All normalized after orchiectomy, and none suffered a recurrence after a median follow-up period of 50 
Table 4. Characteristics of the patients with relapse in stage IIA/B

\begin{tabular}{|c|c|c|c|c|c|c|c|c|c|c|c|}
\hline No. & Stage $^{\mathrm{a}}$ & HCG & $\begin{array}{l}\text { Radiation } \\
\text { Gyb }\end{array}$ & $\begin{array}{l}\text { Time to } \\
\text { relapse } \\
\text { months }\end{array}$ & $\begin{array}{l}\text { Localization of } \\
\text { relapse }\end{array}$ & $\begin{array}{l}\text { Marker } \\
\text { AFP }\end{array}$ & $\begin{array}{l}\text { Elevated } \\
\text { HCG }\end{array}$ & $\begin{array}{l}\text { Elevated } \\
\text { LDH }\end{array}$ & $\begin{array}{l}\text { Relapse } \\
\text { PIAP }\end{array}$ & $\begin{array}{l}\text { Treatment } \\
\text { of relapse }\end{array}$ & $\begin{array}{l}\text { Outcome } \\
\text { months }\end{array}$ \\
\hline $8007 / 01$ & $\mathrm{IIB}_{2}$ & + & $\mathrm{P} 42$ & 24 & mediastinum & - & + & + & $?$ & $\begin{array}{l}4 \times \\
\text { carboplatin }\end{array}$ & NED 52 \\
\hline A110/01 & $\mathrm{IIB}_{2}$ & + & P 38 & 24 & retroperitoneum & - & + & + & + & $4 \times$ PEB & NED 17 \\
\hline $5600 / 04$ & $\mathrm{IIB}_{2}$ & + & $\mathrm{P}+\mathrm{S} 40$ & 4 & bone & $?$ & $?$ & + & $?$ & $\begin{array}{l}\text { radiation, } \\
\text { surgery, } \\
4 \times \mathrm{PEB}\end{array}$ & DOD \\
\hline $5600 / 08$ & $\mathrm{IIB}_{2}$ & + & $\mathrm{P}+\mathrm{S} 36$ & 9 & marker only & - & + & - & $?$ & $\begin{array}{l}1 \times \mathrm{PEB} \\
\text { radiation }\end{array}$ & NED 42 \\
\hline $5600 / 09$ & $\mathrm{IIB}_{2}$ & + & P 36 & 6 & bone & - & + & $?$ & $?$ & $4 \times$ PEB & DOD \\
\hline $2007 / 51$ & $\mathrm{IIB}_{1}$ & + & $\mathrm{P} 40$ & 15 & retrosternal & - & + & - & $?$ & $3 \times$ PEB & $\begin{array}{l}\text { lost to } \\
\text { follow-up }\end{array}$ \\
\hline $7000 / 04$ & $\mathrm{IIB}_{2}$ & - & P 29 & 12 & retroperitoneum & $?$ & $?$ & $?$ & $?$ & $\begin{array}{l}\text { surgery + } \\
\text { radiation }\end{array}$ & $\begin{array}{l}\text { lost to } \\
\text { follow-up }\end{array}$ \\
\hline $1004 / 25$ & $\mathrm{IIB}_{2}$ & - & P 36 & 15 & $\begin{array}{l}\text { retroperitoneal + } \\
\text { pulmonal }\end{array}$ & $?$ & $?$ & $?$ & $?$ & $4 \times \mathrm{PEB}$ & NED 48 \\
\hline $8007 / 08$ & $\mathrm{IIB}_{1}$ & - & P 40 & 2 & bone & - & + & + & - & $4 \times \mathrm{VIP}$ & NED 45 \\
\hline
\end{tabular}

Stage $\mathrm{IIB}_{1}=$ Lymph node metastases $<2 \mathrm{~cm} ; \mathrm{IIB}_{2}=$ lymph node metastases $2-5 \mathrm{~cm}$.

$\mathrm{P}=$ Periaortal; $\mathrm{S}=$ supradiaphragmal.

NED $=$ No evidence of disease DOD = died of disease .

months. In our literature review we found no difference between HCG-positive and HCG-negative seminomas in stage I. A poorer outcome was demonstrated only in metastatic (and unknown) stages.

According to our results, the prognosis was excellent when standard therapy was applied (radiotherapy in stages I-IIB and polychemotherapy and/or surgery for residuals in stages IIC/III) after a median follow-up period of 36 months. Only $6 \%$ of the entire group relapsed, and $98 \%$ are alive and free from disease. There was no difference between HCG-positive and HCG-negative seminomas. All stages had comparable relapse and survival rates.

In none of our analyses we found an influence of HCG on the prognosis. This is valid for the simple preoperative HCG elevation and values $>200 \mathrm{U} / \mathrm{l}$ as well. The limit of $200 \mathrm{U} / \mathrm{l}$ was defined at the Consensus Meeting in Hull [21]: As to the experience of most of the participants, high HCG titers were predominantly observed in bulky tumors which require chemotherapy anyway. For the expected small number of patients with seminomas with HCG titers $>200 \mathrm{U} / 1$ and small metastatic lymph nodes, the participants precautiously recommended chemotherapy. Our results conclude this would apply to only $3 \%$ of all seminomas and to $8 \%$ of the HCG-positive seminomas.

In contrast, patients with elevated LDH levels had a significantly worse prognosis $(p=0.015)$, and those with elevated PIAP showed a trend to a poorer outcome ( $p=$ $0.073)$ than patients with normal marker values. The calculation of the relative risk discovered only clinical stage and the elevation of the LDH concentration and its prolonged marker decay as independent prognostic factors. Interestingly, stage IIB patients had the worst therapeutic outcome as compared with all other stages when standard therapy was applied. As even more advanced stages had a more favorable outcome, it must be concluded that radiotherapy for stage IIB seminomas should no longer be regarded as standard therapy. After radiotherapy, the relapse-free survival rate was only $75 \%$ for HCG-positive and $76 \%$ for HCG-negative seminomas. A comparison 
Table 5. Literature review of the results of radiotherapy in stage IIA/B seminoma

\begin{tabular}{|c|c|c|c|c|c|c|}
\hline \multirow[t]{2}{*}{ Authors } & \multirow{2}{*}{$\begin{array}{l}\text { Year of } \\
\text { publication }\end{array}$} & \multirow[t]{2}{*}{$\mathrm{n}$} & \multirow{2}{*}{$\begin{array}{l}\text { Relapse-free } \\
\text { survival, } \%\end{array}$} & \multirow{2}{*}{$\begin{array}{l}\text { Survival } \\
\%\end{array}$} & \multicolumn{2}{|c|}{ Relapse rates, $\%$} \\
\hline & & & & & IIA & IIB \\
\hline Evensen et al. [9] & 1985 & 24 & 96 & 100 & 0 & 6 \\
\hline Gregory and Peckham [12] & 1986 & 39 & 87 & 95 & 11 & 18 \\
\hline Zagars and Babian [36] & 1987 & 37 & 95 & 95 & $?$ & $?$ \\
\hline Mason and Kearsley [37] & 1988 & 25 & 96 & 96 & $?$ & $?$ \\
\hline Pfannmüller-Schurr et al. [35] & 1988 & 69 & 88 & $?$ & $\dot{0}$ & 24 \\
\hline Kellokumpu-Lehtinen and Halme [15] & 1990 & 56 & 82 & 94 & $?$ & $?$ \\
\hline Bayens et al. [34] & 1992 & 29 & 76 & 93 & 0 & 33 \\
\hline Hanks et al. [13] & 1992 & 107 & 96 & 97 & $?$ & $?$ \\
\hline Gospodarowicz et al. [11] & 1994 & 56 & 89 & 96 & 12 & 9 \\
\hline Present series & & 80 & 87 & 97 & 2 & 24 \\
\hline Overall & & 522 & 90 & 96 & 7 & 22 \\
\hline
\end{tabular}

Table 6. Relapse sites $(n=28)$ after radiotherapy in stage IIA/B seminomas [11, 12, $15,34]$ (multiple sites possible)

\begin{tabular}{lr}
\hline Localization & $\mathrm{n}$ \\
\hline Abdomen & 6 \\
Mediastinal/supraclavicular, & \\
$\quad$ or supradiaphragmatic & 14 \\
Pulmonal & 5 \\
Hepatic & 1 \\
Bones & 6 \\
Miscellaneous & 3 \\
\hline
\end{tabular}

with other published results was hampered by the fact that most radiotherapists use classifications that do not allow a safe differentiation of stages IIA and IIB from higher stages. Some even classify lymph node masses of up to $10 \mathrm{~cm}$ as IIA [8]. We summarized the data of seminomas with low-volume metastases, considering only reports with at least 20 cases in stage IIA/B (table 5), and found the same trend as in our study. Patients with metastases between 2 and $5 \mathrm{~cm}$ had a recurrence rate of $22 \%$ (range $6-40 \%)[12,34,35]$. Most of the relapses are localized outside the retroperitoneum (table 6), presuming a systemic disease which requires systemic therapy. $30 \%$ of the relapsing patients died of their disease. Despite the small number of cases evaluated, we recommend chemotherapy for these patients, especially because patients with stage IIC/III had a better outcome after chemotherapy than those with stage IIB after radiotherapy.

\section{Concluding Remarks}

HCG-positive seminomas have significantly higher stages than those with normal values in the cubital vein. HCG has no negative influence on the relapse rate of seminomas. The risk of relapse is higher for patients with $\mathrm{pT}$ category higher than 1 and for those with elevated LDH levels. Obviously, seminomas - irrespective of their HCG status - are sufficiently treated by the current standard therapy. Therapy should only be altered in stage IIB (metastases $2-5 \mathrm{~cm}$ ), as local radiotherapy cannot prevent the demonstrated systemic relapses. Therapy recommendations are radiotherapy for patients with clinical stages I and IIA (no lymph node metastases or $<2 \mathrm{~cm}$ ) and chemotherapy for patients with lymph nodes $>2 \mathrm{~cm}$ or distant metastases.

\section{Acknowledgment}

This work was supported by the Ministry of Research and Technology of the Federal Republic of Germany (Grant No. 0701915). 


\section{References}

1 Rustin GJS, Vogelzang NJ, Sleijfer DT, Nisselbaum JN: Consensus Statement on Circulating Tumour Markers and Staging Patients with Germ Cell Tumours. EORTC Genitourinary Group Monograph 7: Prostate Cancer and Testicular Cancer. New York, Wiley-Liss, 1990, pp 277-284.

2 Henkel K, Tschubel K, Bussar-Maatz R: Die Morphologie des HCG-positiven Seminoms; in Weissbach L, Hildenbrand G (eds): Register und Verbund-Studie für Hodentumoren Bonn. Ergebnisse einer prospektiven Untersuchung. München, Zuckschwerdt, 1982, pp 7382 .

3 Kurmann RJ, Scardino PT, McIntire KR, Waldmann TA, Javadpour N: Cellular localization of a-fetoprotein and human chorionic gonadotropin in germ cell tumors of the testis using an indirect immunoperoxidase technique. Cancer 1977;40:2136.

4 Mumperow E, Hartmann M: Spermatic $\operatorname{cord} \beta$ human chorionic gonadotropin levels in seminoma and their clinical implications. J Urol 1992;147:1041-1043.

5 Weissbach L, Bussar-Maatz R: HCG-positive seminoma. Eur Urol 1993;23(suppl 2):29-32.

6 Butcher DN, Gregory WM, Gunter PA, Masters JRW, Parkinson MC: The biological and clinical significance of HCG-containing cells in seminoma. Br J Cancer 1985;51:473-478.

7 Caillaud JM, Bellet D: Etude par immunoperoxydase de 80 tumeurs germinales testiculaires de l'adulte. Nouv Presse Méd 1981;10: 1057-1060.

8 Dosmann MA, Zagars GK: Post-orchiectomy radiotherapy for stages I and II testicular seminoma. Int J Radiat Oncol Biol Phys 1993;26: 381-390.

9 Evensen JF, Fossa SD, Kjellevold K, Lien HH: Testicular seminoma: Analysis of treatment and failure for stage II disease. Radiother Oncol 1985; 4:55-61.

10 Fossa A, Fossa SD: Serum lactate dehydrogenase and human choriogonadotrophin in seminoma. Br J Urol 1989;63:408-415.

11 Gospodarowicz MK, Warde PR, Pazarella T, et al: The Princess Margaret Hospital experience in the management of stage I and II seminoma - 1981 to 1991; in Jones WG, Harnden P, Appleyard I (eds): Germ Cell Tumours. Oxford, Pergamon Press, 1994, vol III, pp $177-$ 186.

12 Gregory C, Peckham MJ: Results of radiotherapy for stage II testicular seminoma. Radiother Oncol 1986;6:285-292.
13 Hanks GE, Peters T, Owen J: Seminoma of the testis: Long-term beneficial and deleterious results of radiation. Int J Radiat Oncol Biol Phys 1992;24:913-919.

14 von Hochstetter AR, Sigg C, Saremaslani P, Hedinger $\mathrm{C}$ : The significance of giant cells in human testicular seminomas. Virchows Arch A Pathol Anat Histopathol 1985;407:309-322.

15 Kellokumpu-Lehtinen P, Halme A: Results of treatment in irradiated testicular seminoma patients. Radiother Oncol 1990;18:1-7.

16 Kratzik C, Kuber W: Metastasierung beim Seminom des Hodens mit besonderer Berücksichtigung des HCG-positiven Seminoms: Eine Registerauswertung. Verhandlungsbericht der 34. Tagung der Deutschen Gesellschaft für Urologie 1982.

17 Lang PH, Nochmovitz LE, Rosai J, et al: Serum alpha-fetoprotein and human chorionic gonadotropin in patients with seminoma. $\mathbf{J}$ Urol 1980;124:473.

18 Mauch P, Weichselbaum R, Botnick L: The significance of positive chorionic gonadotropins in apparently pure seminoma of the testis. Int $\mathbf{J}$ Radiat Oncol Biol Phys 1979;5:887-889.

19 Mirimanoff RO, Shipley WU, Dosoretz DE, Meyer JE: Pure seminoma of the testis: The results of radiation therapy in patients with elevated human chorionic gonadotropin titers. J Urol 1985;134:1124-1126.

20 Dieckmann KP, Düe W, Bauer HW: Seminoma testis with elevated serum beta-HCG - a category of germ cell cancer between seminoma and nonseminoma. Int Urol Nephrol 1989;21: 175-184.

21 Thomas G, Jones W, van Oosterom A, Kawai $\mathrm{T}$ : Consensus statement on the investigation and management of testicular seminoma 1989; in Newling DWW, Jones WG (eds): Prostate Cancer and Testicular Cancer. New York, Wiley-Liss, 1990, pp 285-294.

22 Hartmann M, Pottek T, Bussar-Maatz R, Weissbach L: Elevated HCG concentrations in the testicular vein and in peripheral venous blood in seminoma patients: An analysis of various parameters. Eur Urol 1997;31:408413.

23 Weissbach L, Bussar-Maatz R, Mann K: The value of tumor markers in testicular seminomas: Results of a prospective multicenter study. Eur Urol 1997;32:13-19.

24 Fossa SD, Risberg T: $\beta$-HCG producing seminoma; in Khoury S, Küss R, Murphy GP, Chatelain C, Karr JP: Testicular Cancer. New York, Liss, 1985, pp 105-106.
25 Mirimanoff RO, Sinzig M, Kruger M, Mirabell R, Thoni A, Ries G, Bosset JF, Bernier J, Bolla M, Nguyen TD, et al: Prognosis of human chorionic gonadotropin producing seminoma treated by postoperative radiotherapy. Int $\mathbf{J}$ Radiat Oncol Biol Phys 1993;27:17-23.

26 Bal D, Barrett A, Peckham MJ: The management of metastatic seminoma testis. Cancer 1982;50:2289-2294.

27 Bartsch G, Mikuz G, Fommhold H, Scheiber $\mathrm{K}$ : Treatment of seminoma: Does a positive HCG influence prognosis? In Khoury S, Küss R, Murphy GP, Chatelain C, Karr JP: Testicular Cancer. New York, Liss, 1985, pp 483484

28 Swartz DA, Johnson DE, Hussey DH: Should an elevated human chorionic gonadotropin titer alter therapy for seminoma? J Urol 1984; 131:63-65.

29 Morgan DAL, Caillaud JM, Bellet D, Eschwege F: Gonadotrophin-producing seminoma: A distinct category of germ cell neoplasm. Clin Radiol 1982;33:149-153.

30 Mostofi FK: Pathology of germ cell tumors of testis: A progress report. Cancer 1980;45: 1735-1754.

31 Percarpio B, Clements JC, McLeod DG, Sorgen SD, Cardinale FS: Anaplastic seminoma: An analysis of 77 patients. Cancer 1979;43: 2510-2513.

32 Roth A, le Pelletier O, Cukier L: Cryptocarcinome trophoblastique à cellules mononuclées sécrétrices d'hormones gonadotrophiques chorioniques bêta dans les séminomes: Valeur pronostique. Presse Méd 1983;12:2801-2804.

33 Schwartz BF, Auman R, Peretsman SJ, Moul JW, Deshon GE, Hernandez J, Rozanski TA, Thrasher JB: Prognostic value of BHCG and local tumor invasion in stage I seminoma of the testis. J Surg Oncol 1996;61:131-133.

34 Bayens YC, Helle PA, Van Putten WLJ, Mali SPM: Orchiectomy followed by radiotherapy in 176 stage I and II testicular seminoma patients: Benefits of a 10-year follow-up study. Radiother Oncol 1992;25:97-102.

35 Pfannmüller-Schurr EL, Hodapp N, Bruggmoser G, Wannenmacher M: Strahlentherapie der Seminome im Stadium II A/B; in Schmoll HJ, Weissbach L (eds): Diagnostik und Therapie von Hodentumoren. Berlin, Springer, 1988, pp 409-414.

36 Zagars GK, Babian RJ: The role of radiation in stage II testicular seminoma. Int J Radiat Oncol Biol Phys 1987; 13:163-170.

37 Mason BR, Kearsley JH: Radiotherapy for stage 2 testicular seminoma: The prognostic influence of tumor bulk. J Clin Oncol 1988;6: 1856-1862. 